\title{
Germination of Native Prairie Forb Seeds
}

\section{J. T. SORENSEN AND D. J. HOLDEN}

Highlight: $A$ study was conducted on 23 tallgrass prairie forb and legume seeds to determine conditions that would lead to a high level of germination. Seed fill was physically determined, seed viability was determined chemically with triphenyl tetrazolium chloride, and germination was done on moist filter paper in petri dishes. Of the 23 species of seeds tested, $69.5 \%$ germinated under normal conditions, $21.7 \%$ required moist-cold treatment, $4.4 \%$ required scarification, and $4.4 \%$ never germinated.

Prairies once occupied an estimated billion acres, or nearly one-fifth of the North American continent, but this community, like no other natural community, has been vastly altered by pioneer settlement. Of the once-vast expanse of central grasslands, only scattered remnants remain. Areas comprising fairly pure tallgrass prairie flora today are limited chiefly to railroad right-of-ways, neglected cemeteries, and certain islands. Due to man's activities, the prairie community has nearly disappeared (Bland, 1970). Kilburn (1970) states that bluffs and banks of rivers, such as the Mississippi, Illinois, Missouri, and Ohio rivers, form the bulk of relict native tall grass prairie stands. In recent years, however, there has been an increased interest in the possibility of replanting and restoring a part of this diverse and beautiful grassland community (Schramm, 1970).

If prairies are to be restored or prairie plants used for landscaping and other commercial uses, there will develop a demand for forb seed which does not exist in sufficient quantity or quality at the present time. This seed source must come from the small relict areas which

The authors are research assistant and professor of botany, respectively, Department of Botany-Biology, South Dakota State University, Brookings.

The report is a contribution from the $\mathrm{De}$ partment of Botany-Biology, South Dakota State Univ., and the South Dakota Agricultural Experiment Station, Brookings. Approved for publication by the dean and director as Journal Series No. 1197.

Man uscript received J une 23, 1973. still possess a gene pool representative of the native prairie. Jenkins (1971) points out that in any natural community there are a few dominant species which are very abundant and a large number of species which are more or less rare. In a prairie in Wisconsin composed of 240 species, 12 species were represented by as many individual plants as all other 228 species combined. It is these 228 species, the majority of which are forbs, that need extensive research; for the grasses can be established with relative ease compared to the forbs. At present the capability to provide commercial sources of native prairie seeds exists only with some grasses and practically none of the forbs. Therefore, it is the purpose of this paper to determine some of the characteristics of native prairie forb seeds which would be useful in establishing these plants in the field.

\section{Methods and Materials}

The Sioux Prairie, 160 acres in size, 20 miles south of Brookings, S. Dak., on Highway 77 (T107N, R50W), was used for the collection of forb seed. This prairie is similar to the Cayler Prairie in northwest Iowa (Aikman and Thorne, 1956).

Several collections were conducted to include spring, summer, and fall flowering forbs. All seeds were collected by hand.

As seed sets, not all seeds fill; consequently, there can be a high proportion of empty seed coats. Therefore, it becomes important to determine filled versus nonfilled seed prior to subjecting the seed to germination tests (Lawrence et al., 1947). This determination was made on ten forbs by physically pinching the seed with forceps.

All filled seeds were tested for viability by soaking for 8 hours in $0.1 \%$ triphenyl tetrazolium chloride (TTC) (Hartmann and Kester, 1968; Machlis and Torrey, 1956). Seeds that have a hard coat were cut in half with a razor blade prior to treatment.

All seeds were subjected to a normal laboratory germination test. They were treated with Arasan, a fungicide, and placed in a petri dish with moist filter paper, as described by Nichols (1934). A growth chamber was used to maintain a constant temperature of $70^{\circ} \mathrm{F}$ (Green and Curtis, 1950; Tolstead, 1941) and complete darkness, except when the seeds were removed for counting germination. This treatment was conducted for a 30-day period with daily recordings of number of seeds which had germinated. Once a seed had germinated it was removed from the petri dish. Seeds were considered germinated once the radicle protruded through the seed coat. One hundred seeds were tested per species, except for those seeds which were limited in number. A germination trial consisted of four replications, 25 seeds per replication. Additional seeds from species which failed to germinate were then subjected to other methods of treatment to determine what method would break seed dormancy.

Seeds were scarified by being placed between two sheets of sandpaper and lightly rubbed (Hartmann and Kester 1968). Because of the limited number of seeds, this method was used to minimize seed destruction. Once scarified, the seeds were germinated in the normal germination procedure.

Thirteen forbs were subjected to a moist-cold treatment. Seeds were placed in a petri dish with a moist filter paper and were chilled in a refrigerator at $38^{\circ} \mathrm{F}$ 
(Bland, 1970; Christiansen, 1967; Hartmann and Kester, 1968) for a period of 1 , 2 , and 3 months. At monthly intervals, 100 seeds were removed and germinated as described in normal germination.

Two forbs, prairie clover (Ratibida columnifera) and wood lily (Lilium philadelphicum), were tested with TTC for an impermeable membrane. Each forb was subjected to two treatments of $0.1 \%$ TTC. In one treatment, the seed membrane was punctured with a probe to allow the TTC to enter the seed. In the second treatment, the seed membrane was not punctured, thus determining whether or not the seed membrane is permeable or impermeable.

Gibberellic acid was used to induce germination of two forbs, water hemlock (Cicuta maculata) and down gentian (Gentiana puberula) (Mayer and Poljakoff-Mayber, 1963). Half of the seeds were soaked in $100 \mathrm{ppm}$ gibberellic acid for a 2-week period and the other half for a 1-month period and germinated as described in normal germination.

\section{Results and Discussion}

Table 1 reveals that seed viability was high, ranging from $92 \%$ to $100 \%$ except for one species, common lousewort (Pedicularis canadensis), which was 58\%. If, therefore, seed is subjected to the right environmental conditions, germination will be successful. Table 2 illustrates that not all seeds collected had matured. Seed development ranged from $24.5 \%$ to 93.3\%. Amen (1963) reports that little information is available on the influence of environmental conditions during flowering and seed set on the subsequent germination of a seed crop. Blake (1935) states that weather conditions during flowering and seed set appear to affect subsequent germination and to account for differences in germination between annual harvest of seeds. Below normal temperature and above-normal rainfall appear to increase subsequent germination, while drought lowers germination.

Not only is seed development a problem in collection, but little is known about the best time for collection. If seeds are left to mature on the plant, they sometimes disperse quickly upon rcaching maturity. This is especially true with the composites. One possible solution to this problem would be to collect seed in the dough stage as is done in some agronomic crops.

Of 23 native prairie forbs, 16 species, or $69.5 \%$, germinated under normal test conditions (Table 3), presenting no real problem for commercial use on a large scale.
Table 1. TTC test of seed viability (\%) of 23 prairie forbs.

\begin{tabular}{lc}
\hline \hline Species & Viability \\
\hline Achillea millefolium & 100 \\
Allium spp. & 100 \\
Amorpha canescens & 92 \\
Anemone cylindrica & 98 \\
Anemone patens & 98 \\
Antennaria spp. & 96.5 \\
Aster sericeus & 100 \\
Astragalus canadensis & 96 \\
Astragalus crassicarpus & 100 \\
Cicuta maculata & 100 \\
Echinacea angustifolia & 100 \\
Erigeron strigosus & $-\mathrm{a}$ \\
Gentiana puberula & 92.3 \\
Geum triflorum & 100 \\
Liatris ligulistylis & $-\mathrm{b}$ \\
Liatris punctata & $-\mathrm{b}$ \\
Lilium philadelphicum & $98^{\mathrm{a}}$ \\
Pedicularis candensis & 58 \\
Petalostemum spp. & 100 \\
Potentilla arguta & 100 \\
Ratibida columnifera & $100^{\mathrm{c}}$ \\
Vernonia fasciculata & 100 \\
Zizia spp. & 100 \\
\hline
\end{tabular}

a - ran out of seed.

$b_{-}$weevils in seed.

c-after puncture treatment.

Only one species in normal germination displayed any unusual characteristics. The purple cone flower (Echinacea angustifolia) was found to have a corky seed covering which, when removed, allowed $92 \%$ germination as opposed to $13 \%$ germination with the corky covering.

The moist-cold treatment was utilized in breaking temperature-dependent dormancy. During this treatment afterripening takes place, resulting in responses such as embryonic growth or metabolic change in the embryo (Hartmann and Kester, 1968; Mayer and Poljakoff-Mayber, 1963). Under this mode of treatment four responses were noted: breaking the dormancy of species which did not germinate under normal conditions, increased germination and rate of germination, decreased germination, and no effect on germination. These same results were also noted by Nichols

Table 2. Percentage of seeds developing mature embryos.

\begin{tabular}{lc}
\hline \hline \multicolumn{1}{c}{ Species } & $\begin{array}{c}\text { Percentage devel- } \\
\text { oping embryos }\end{array}$ \\
\hline Amenome patens & 91.2 \\
Amorpha canescens & 81.0 \\
Aster sericeus & 42.0 \\
Echinacea angust ifolia & 76.5 \\
Geum triflorum & 93.3 \\
Liatris ligulistylis & 66.5 \\
Liatris punctata & 76.5 \\
Petalostemum spp. & 24.5 \\
Ratibida columnifera & 47.5 \\
Vernonia fasciculata & 54.5 \\
\hline
\end{tabular}

(1934) where he states stratification benefited $73 \%$ and harmed $14 \%$ of the species. Tolstead (1941), Christiansen (1967), and Blake (1935) found the same basic response to stratification.

Moist-cold treatment broke the seed dormancy of tall cinquefoil (Potentilla arguta) after 1 month (Table 4). Both pussytoes (Antennaria spp.) and alexander (Zizia spp.) increased percent germination and rate of germination with incrcasing cold period. Daisy fleabane (Erigeron strigosus) decreased in percent germination under cold treatment, starting with $70 \%$ normal germination, $16 \%$ after 1 month cold treatment and $0 \%$ after 2 months treatment. Meadow anemone (Anemone cylindrica) illustrates that the cold treatment did not effect percent germination but did increase rate of germination. In fact, cold treatment incrcased the rate of germination of all species tested except common yarrow (Achillea millefolium), which decreased in percent germination as well as rate of germination.

Table 5 illustrates the effect of the 3 -month moist-cold treatment on 3 of the 23 species tested. In this table a comparison can be made with percent germination to length of cold treatment and duration of germination. Western ironweed (Vernonia fasciculata) presented an interesting aspect of secondary dormancy. This species germinated after 1 month of cold treatment and failed to germinate after 2 months. However, after 3 months, western ironweed started to germinate again. While western ironweed was undergoing moist-cold treatment, the petri dishes became somewhat dry. Hartmann and Kester (1968) state that with drying seeds in moist-cold treatment will go into secondary dormancy.

A widespread cause of seed dormancy is the presence of a seed coat, usually a multi-layered membrane (Mayer and Poljakoff-Mayber, 1963). A hard seed coat is resistant to abrasion and may be covered with waxlike layers, resulting in impermeability to water, impermeability to gases, or mechanical constraint of the embryo.

The method most commonly used to break seed coat dormancy is scarification. The results of this study show that four species benefited from scarification, all in the family Leguminosae. This family has a hard seed coat impermeable to water. Scarification broke seed dormancy, and increased the percent germination and rate of germination of those seeds tested (Table 6). 
Table 3. Normal seed germination of $\mathbf{2 3}$ prairie forbs.

\begin{tabular}{lcccc}
\hline & & & \multicolumn{2}{c}{ Days required } \\
\cline { 4 - 5 } \multicolumn{1}{c}{ Species } & $\begin{array}{c}\text { Germina- } \\
\text { tion }(\%)\end{array}$ & $\begin{array}{c}\text { Days to } \\
\text { germinate }\end{array}$ & $\begin{array}{c}50 \% \text { ger- } \\
\text { mination }\end{array}$ & $\begin{array}{c}75 \% \text { ger- } \\
\text { mination }\end{array}$ \\
\hline Achillea millefolium & 87 & $2-8$ & 3 & 5 \\
Allium spp. & $36.7^{\mathrm{a}}$ & $16-23$ & - & - \\
Amorpha canescens & 63 & $2-18$ & 8 & - \\
Anemone cylindrica & 96 & $13-23$ & 13 & 14 \\
Anemne patens & 78 & $11-24$ & 17 & 19 \\
Antennaria spp. & 2 & $7-11$ & - & - \\
Aster sericeus & 71 & $2-24$ & 6 & - \\
Astragalus canadensis & 8 & $4-9$ & - & - \\
Astragalus crassicarpus & 0 & - & - & - \\
Cicuta maculata & 0 & - & - & - \\
Echinacea angustifolia & $92^{\mathrm{b}}$ & $2-9$ & 4 & 6 \\
" & $13^{\mathrm{c}}$ & $5-11$ & - & - \\
Erigeron strigosus & 70 & $3-18$ & 6 & - \\
Gentiana puberula & 0 & - & - & - \\
Geum triflorum & 90 & $7-16$ & 10 & 12 \\
Liatris ligulistylis & 41 & $4-26$ & - & - \\
Liatris punctata & 47 & $8-22$ & - & - \\
Lilium philadelphicum & $30^{\mathrm{d}}$ & $9-17$ & - & - \\
Pedicularis candensis & 0 & - & - & - \\
Petalostemum spp. & 2 & $3-4$ & - & - \\
Potentilla arguta & 0 & - & - & - \\
Ratibida columnifera & 0 & - & - & - \\
Vernonia fasciculata & 0 & - & - & - \\
Zizia spp. & 4 & $10-18$ & - & - \\
\hline a based & & & &
\end{tabular}

a_based on 30 seeds.

b_hull removed.

c-hull not removed.

$c_{-b}$ ased on 50 seeds.
Table 4. Seed germination of 10 prairie forbs after 1 and 2 months moist-cold treatment (MCT).

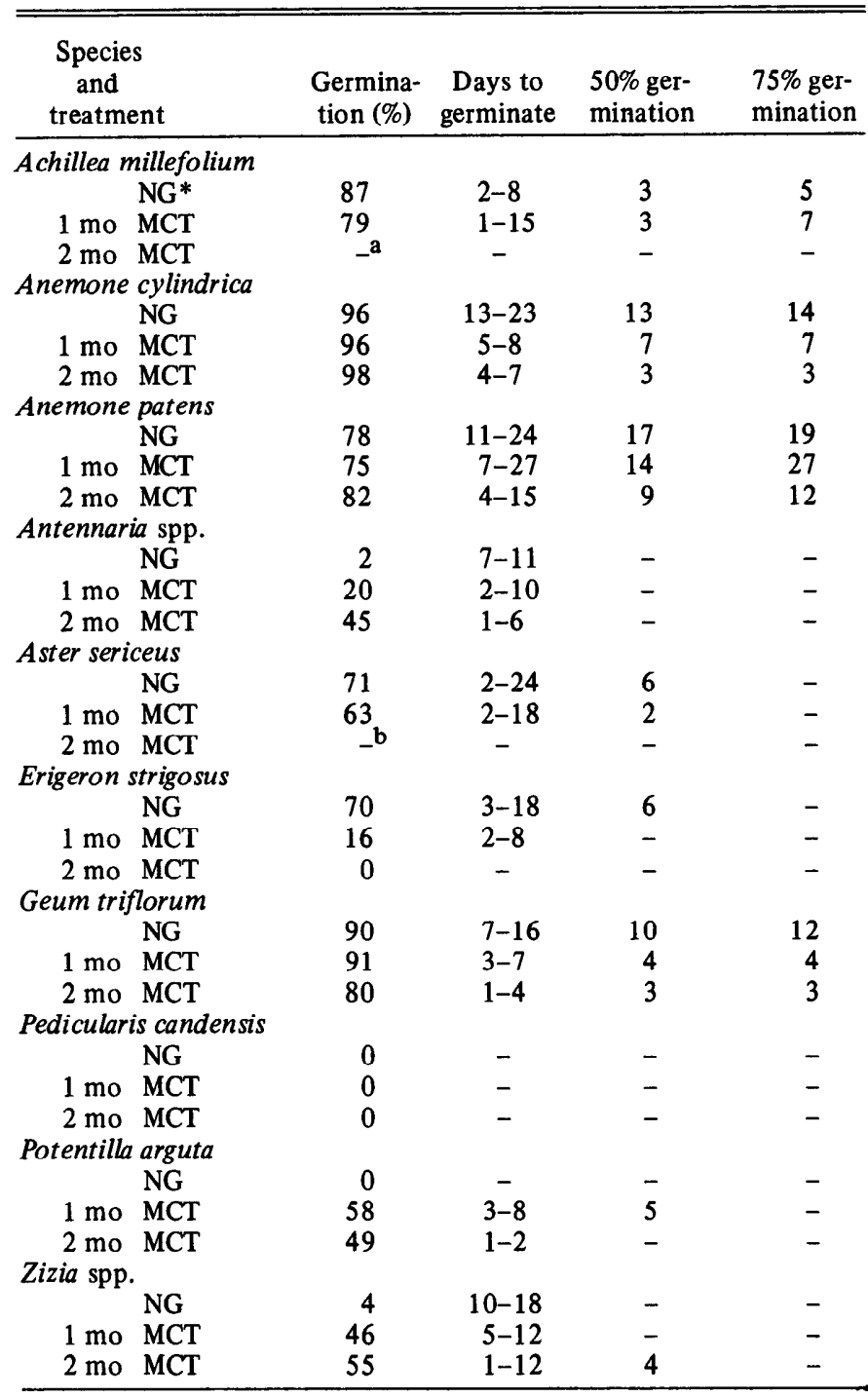

${ }^{\text {a Seeds had heavy mold. }}$

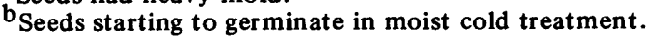

*Normal germination.

\begin{tabular}{ccc}
\hline $\begin{array}{l}\text { Species and } \\
\text { treatments }\end{array}$ & Germination & $\begin{array}{c}\text { Days to } \\
\text { germinate }\end{array}$ \\
\hline $\begin{array}{c}\text { Cicuta maculata } \\
\text { NG* }\end{array}$ & 0 & - \\
1 mo MCT & 0 & - \\
2 mo MCT & 5 & $4-5$ \\
3 mo MCT & 37 & $1-9$ \\
Gentiana puberula & & \\
NG & 0 & - \\
1 mo MCT & 0 & - \\
2 mo MCT & 32 & $3-13$ \\
3 mo MCT & 55 & $1-8$ \\
Vernonia fasciculata & & \\
NG & 0 & - \\
1 mo MCT & 38 & 3 \\
2 mo MCT & 0 & - \\
3 mo MCT & 24 & $2-5$ \\
\hline
\end{tabular}
(MCT).

*Normal germination.

Table 5. Seed germination (\%) of 3 prairie forbs after three months moist-cold treatment

\section{t}

.


Table 7. Germination (\%) of seeds treated to determine the influence of membrane surrounding the embryo in two forbs.

\begin{tabular}{|c|c|c|c|c|c|c|c|c|}
\hline \multirow[b]{2}{*}{ Species } & \multicolumn{3}{|c|}{$\mathrm{NG}^{*}$} & \multicolumn{2}{|c|}{ TTC** } & \multirow{2}{*}{$\begin{array}{c}\text { Acetone } \\
\& \text { TTC }\end{array}$} & \multirow{2}{*}{$\begin{array}{l}\text { Ether } \\
\& \text { TTC }\end{array}$} & \multirow[b]{2}{*}{ MCT *** } \\
\hline & No & puncture & Puncture & No puncture & Puncture & & & \\
\hline $\begin{array}{l}\text { Ratibida } \\
\text { columnifer }\end{array}$ & & 0 & 95 & 0 & 100 & 0 & 0 & 11 \\
\hline $\begin{array}{l}\text { Lilium } \\
\text { philadelph }\end{array}$ & & $30^{\mathrm{a}}$ & $79^{c}$ & 0 & 98 & 0 & 0 & $66^{b}$ \\
\hline
\end{tabular}

Not only does seed dormancy result from a hard seed coat but also from a membrane impervious to water or gases. Both prairie coneflower and wood lily have this characteristic (Table 7). Both benefited from puncture, indicating an impermeable membrane or wax coating. Tests with TTC treatment without puncture of the membrane indicated a colorless embryo or nonviable seeds. After puncture prairie coneflower had 100\% and wood lily $98 \%$ red embryos, which indicates the barrier is to water. The membrane coating of wood lily is less impermeable than prairie coneflower, for under normal germination condition wood lily germinated $30 \%$ and prairie coneflower $0 \%$.

Seeds which fail to germinate or require extra long treatments to break dormancy can be subjected to stimulants, such as hormones, which may shorten the time needed to germinate or break dormancy. Both water hemlock and downy gentian germinated when subjected to the moist-cold treatment but required the longest time of any species, and germination was low. Both species were treated with gibberellic acid, which shortened the time required for germination of downy gentian but had no effect on water hemlock (Table 8). Mayer and PoljakoffMayber (1963) state that gibberellic acid has the ability to reverse the inhibition of germination caused by high osmotic pressure. Cleland (1969) states gibberellic acid can activate amylase in the endosperm. Amylase is a hydrolytic enzyme which converts the starch in the endosperm to glucose, which then can be utilized by the embryo as energy for growth.

Pedicularis canadensis was the only species out of 23 in which the seeds failed to germinate. It is difficult to say why. Its failure to germinate could be contributed to the fact that the seed had not matured, for seed viability was only $58 \%$. Those which indicated viability may not have been physiologically or morphologically developed enough to germinate, thus requiring a longer time for after-ripening.

\section{Summary}

Although there is not a large quantity of native prairie forb seed available, this study as well as others indicates that native forb seed can be successfully germinated. Seed viability poses no real problem, but seed set does present some difficulties. However, once this seed is raised agronomically, environmental conditions can be controlled to some extent, and seed set will probably no longer be a problem. At present, seed collection is a laborious process; but once these forbs are raised as one-stand crops, mechanization will solve the problem in collection.

Of 23 species studied it was found that $69.5 \%$ (16 species) germinated under normal germination, $21.7 \%$ (5 species) required moist-cold treatment before the seeds would germinate, $4.4 \%$ ( 1 species) required scarification before germination, and $4.4 \%$ (1 species) never germinated.

Of 13 species subjected to moist-cold treatment it was found that there were four responses: $30.7 \%$ germinated only after cold treatment, $23.1 \%$ increased in germination percentage, $15.3 \%$ showed no effect, and moist-cold treatment was harmful to $30.7 \%$. These same four re-

Table 8. Germination (\%) of seed of two forbs treated with gibberellic acid.

\begin{tabular}{lcc}
\hline Species & Germination & $\begin{array}{c}\text { Days to } \\
\text { germinate }\end{array}$ \\
\hline Cicuta maculata & & \\
$\quad$ NG* & 0 & - \\
2 week & 0 & - \\
1 month & 0 & - \\
Gent iana puberula & & \\
$\quad$ NG & 0 & - \\
2 week & 30 & $7-25$ \\
1 month & 36 & $4-22$ \\
\hline
\end{tabular}

*Normal germination. sponses have also been found in other studies of cold treatment.

Scarification was beneficial to four species and harmful to three. It should also be noted that scarification not only broke seed dormancy, but on those seeds which germinated normally, scarification increased the rate of germination. Other studies have also found scarification to have this same effect.

Chemical induction of germination with gibberellic acid was beneficial to only one of the two species tested.

\section{Literature Cited}

Aikman, J. M., and Robert F. Thorne. 1956. The Cayler Prairie: An ecological and taxonomic study of a northwest Iowa prairie. Proc. of the Iowa Acad. of Sci. 63:177-200.

Amen, R. D. 1963. The concept of seed dormancy. Amer. Sci. 51:409-424.

Blake, Abigail K. 1935. Viability and germination of seeds and early life history of prairie plants. Ecol. Monogr. 5:405-460.

Bland, Marilyn K. 1970. Prairie establishment at the Michigan botanical gardens. Proceedings of a symposium on Prairie and Prairie Restoration. Knox College, Galesburg, Illinois, p. 46-47.

Christiansen, Paul A. 1967. Establishment of prairie species in Iowa by seeding and transplanting. PhD thesis, Iowa State University.

Cleland, Robert E. 1969. Physiology of plant growth and development. Ed. Malcolm B. Wilkins. McGraw-Hill. New York, p. 49-81.

Green, H. C., and J. T. Curtis. 1950. Germination studies of Wisconsin prairie plants. Amer. Midland Natur. 43:186-194.

Hartmann, Hudson T., and Dale E. Kester. 1968. Plant propagation principles and practices. Prentice-Hall, Inc., Englewood Cliffs, New Jersey, p. 102, 127, 156.

Jenkins, Robert E. 1971. Prairie management: The care and treatment of a dynamic ecosystem. The Nature Conserv. News 21:12-14.

Kilburn, Paul D. 1970. Hill prairie restoration. Proceedings of a Symposium of Prairie and Prairie Restoration. Knox College, Galesburg, Illinois, p. 50-51.

Lawrence, D. B., E. G. Lawrence, and A. L. Seim. 1947. Data essential to completeness of native plants. Ecology 28:76-78.

Machlis, Leonard, and John G. Torrey. 1956. Plants in action-a laboratory manual of plant physiology. W. H. Freeman and Co. San Francisco, p. 28, 36, 44-46.

Mayer, A. M., and A. Poljakoff-Mayber. 1963. The germination of seeds. The Macmillan Company. New York, p. 61-98.

Nichols, G. E. 1934. The influence of exposure to winter temperatures upon seed germination in various native $\Lambda$ merican plants. Ecology 15:364-373.

Schramm, Peter. 1970. A practical restoration method for tall-grass prairie. Proceedings of a Symposium on Prairie and Prairie Restoration. Knox College, Galesburg, Illinois, 63-65.

Tolstead, W. L. 1941. Germination habits of certain sand-hill plants in Nebraska. Ecology 22:393-397. 